\title{
Gross Body Composition of Laboratory-Bred Pitymys subterraneus
}

\author{
Anna FEDYK, Denise FARIN \& Elżbieta MALZAHN
}

\begin{abstract}
Fedyk A., Farin D. \& Malzahn E., 1978: Gross body composition of laboratory-bred Pitymys subterraneus. Acta theriol., 23, 24: 259-267 [With 4 Figs. \& 2 Tables].

Examination was made of the rate of changes in the quantitative composition of fat, water, protein and mineral substances and in the proportions of components of fat-free body (FFB) of laboratory-bred Pitymys subterraneus during the course of postnatal development. A high degree of correlation was found between body weight and the amount of fat contained in it. The greatest amount of fat is deposited during the first 20 days of life. Rate of increase in FFB depends on reciprocally correlated increase in its components, the participation of which varies greatly during postnatal development. When kept in captivity, Pitymys subterraneus attains chemical maturity, expressed in the quotient of protein and water contents, between the the 50 th and 60 th day of life.
\end{abstract}

[Mammals Res. Inst. Polish Acad. Sci., 17-230 Białowieża, Poland]

\section{INTRODUCTION}

One of the criteria of postnatal development characterizing the species is the growth rate, the measure of which is increase in body mass per unit of time. Rate of increase in biomass has been examined in all species of mammals bred by humans and many wild species kept in captivity. Rate in increase in gross body composition $(G B C)$ has, however, been examined in greatest detail in animals bred on an industrial scale. In the case of rodents $G B C$ has been examined chiefly in the seasonal aspect ( $\mathrm{J}$ a m e s on \& M e a d, 1964; Gó r e cki, 1965; H a yward, 1965; Evans, 1973; Fleharty et al., 1973; S awicka-Kapusta, 1974; Schreiber \& Johnson, 1975). Dynamics of changes in $G B C$ during the course of postnatal growth has been exhaustively studied only in the laboratory mouse Mus musculus (B a iley et al., 1960; S obel et al., 1968) and among wild species only in the bank vole Clethrionomys glareolus (F e d y k, 1974a; 1974b; Sawicka-Kapusta, 1974) and common vole Microtus agrestis (S a wi cka-Ka pusta, 1970; D rożdż et al., 1972).

The purpose of the present study was to measure $G B C$ in European pine voles (Pitymys subterraneus) during postnatal development. This 
species is bred in the laboratories of the Mammals Research Institute, Polish Academy of Sciences, at Białowieża.

\section{MATERIAL AND METHODS}

The pine voles taken for the studies constituted the 9-11th brother $\mathrm{X}$ sister generation born in captivity during 1972. Laboratory breeding conditions and feeding of the animals were identical with those described earlier ( $\mathrm{Buch}$ a l$\mathrm{czyk}, 1961$ ). The young animals were taken from their parents on the 20 th day of life and each litter reared separately. Analysis was made of 159 pine voles from 1 to 400 days old, examining animals up to the 60 th day of life in $1-3$ day intervals of time (taking 1-4 individuals in each case), and the older animals in irregular age groups. Animals intended for analysis were anaesthetized with ether, and the following determined in the eviscerated carcass: water content, ether extract (termed fat in the further part of this paper), protein and mineral substances by the methods described earlier (F e d $\mathrm{k}, 1974 \mathrm{a}$ ). The results obtained were elaborated statistically, describing the relation between eviscerated body weight and the amount of fat by means of straight line regression and the percentage of protein, water and mineral substances in the fat-free body (FFB) by means of multiple regression. The above regressions were calculated for the whole study of development. In order to show differences in rate of deposit of the different components of FFB during postnatal development the above relations were also calculated for four age groups. The $F$-Snedecor test, with $P=0.001$, was used to check the significance of differences in growth rate of fat and FFB components in the age groups distinguished. Where there were no significant differences the relations in similar groups were described by a common equation. Statistical calculations were made by the Computer Centre of the Polish Academy of Sciences in Warsaw.

\section{RESULTS}

During the 400 days of postnatal development there is an almost eightfold increase in the weight of the pine vole, variation in the animals' weight at a given age increasing as development proceeds (Fig. 1). The amount of water in the organism during this period increases on an average from $1.63 \mathrm{~g}$ on the first day of life to $8.60 \mathrm{~g}$ (over $400 \%$ ), the amount of protein increases from $0.23 \mathrm{~g}$ to $2.25 \mathrm{~g}$ $(870 \%)$ and the amount of mineral substances from about $0.04 \mathrm{~g}$ to $0.53 \mathrm{~g}$ (over $1200 \%$ ). The greatest range of variation among the components examined is found for fat, but the relation between body weight and amount of fat it contains - as also among the remaining less variable body components - is statistically significant (Table 1). Most rapid increase in fat takes place during the first 20 days of life (age group I) and is about 3.6 times more intensive than during the subsequent 20 days of life (Fig. 2). Rate of increase in fat similar to that in age group II is characteristic of pine voles between the 41st and 60th 
day of life. Pine voles over two months old exhibit the slowest rate of increase in fat. Among the four periods of development distinguished (=age groups) the rate of increase in fat during the II and III period is not significantly different, and therefore these two periods may be described by a common equation (Table 1). Average rate of increase in fat between the 21st and 60th day of life of these animals is then about $73 \%$ lower than it is during the first 20 days of life. Rapid increase in fat during the first 20 days of life (while still sucking the mother's milk) affects the average relation for the 400-day period of development between amount of fat and body weight - it is slightly higher than between the 21st and 60th day of life.

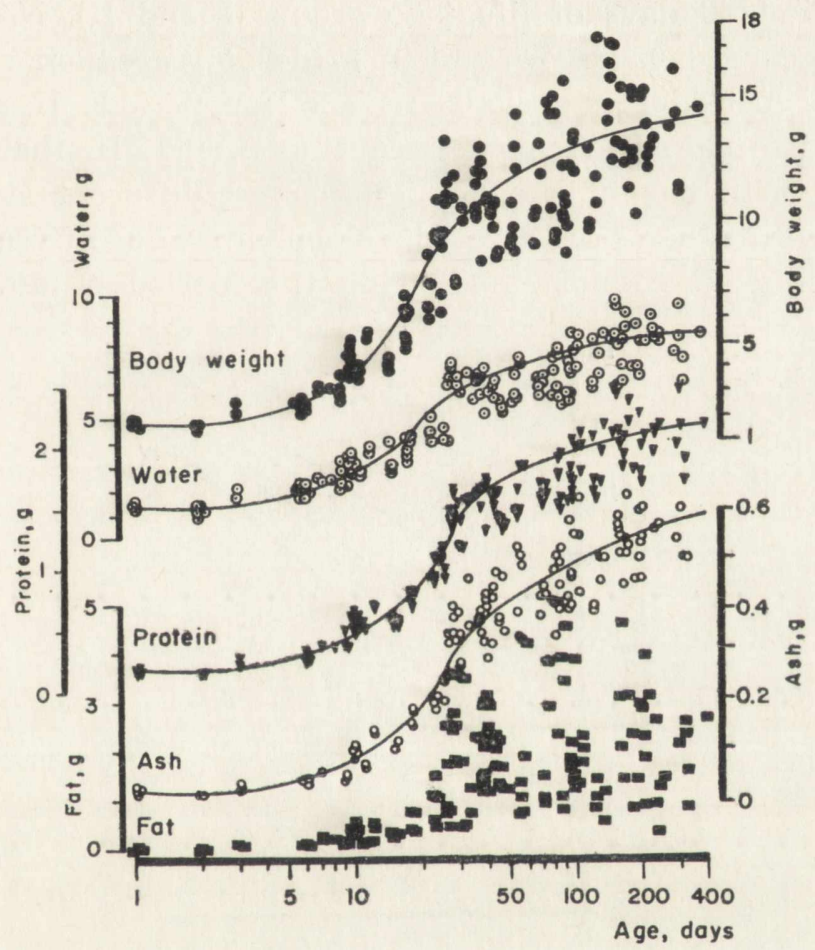

Fig. 1. Quantitative increase of gross body composition and body weight during postnatal development in P. subterraneus. Semi-logarithmic scale.

The simultaneous participation of water, protein and minerai substances in the structure of FFB is shown in Table 2. During the study development period protein, then water and mineral substances, exert the greatest influence on increase in $F F B$, but the participation of these components varies at different stages of development. Nevertheless pine voles are characterized by a similar rate of increase in FFB components 
Table 1

Relation between eviscerated body weight $(Y)$ and amount of fat $(X)$ at different. stages of development and basic characteristics of regression equations: $r$ - coefficient of correlation, $s$-standard error of estimate, $s_{B}$ - standard error or regression coefficient.

\begin{tabular}{cccrc}
\hline Age groups (days) & $Y=A+B X$ & $r$ & $s$ & $s_{B}$ \\
\hline I $(1-20)$ & $Y=2.080+6.277 X$ & .926 & .505 & .357 \\
II $(21-40)$ & $Y=6.876+1.721 X$ & .821 & 1.167 & .215 \\
III $(41-60)$ & $Y=7.582+1.577 X$ & .873 & .789 & .255 \\
IV $(61-400)$ & $Y=9.745+1.435 X$ & .809 & 1.436 & .129 \\
I-IV $(1-400)$ & $Y=4.923+2.762 X$ & .850 & 2.322 & .136 \\
Together II and III & $Y=6.890+1.687$ & & & \\
\hline
\end{tabular}

during the first 40 days of life (age groups I and II). Non-significant differences occur when comparison in made of regression equations for the I and IV period of development and for periods II and IV. The rate of increase in FFB components during period III, that is, between the 41 st and 60 th day of life, is significantly different statistically in comparisor. with other periods of development. The different character of increase in FFB components during this period of development is

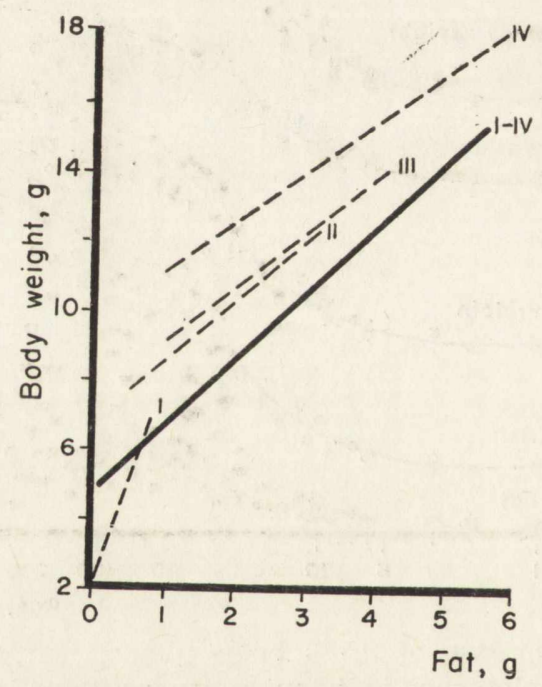

Fig. 2. Relation between body weight and amount of fat contained in it at different stages of development. Mean relation between the parameters examined for 400 days of development is indicated by thick line.

particularly clear when comparing the different components (Fig. 3). The percentage of protein is unsually high, in comparison with other development periods, and the percentage of water and mineral substances particularly low, during the third period. 


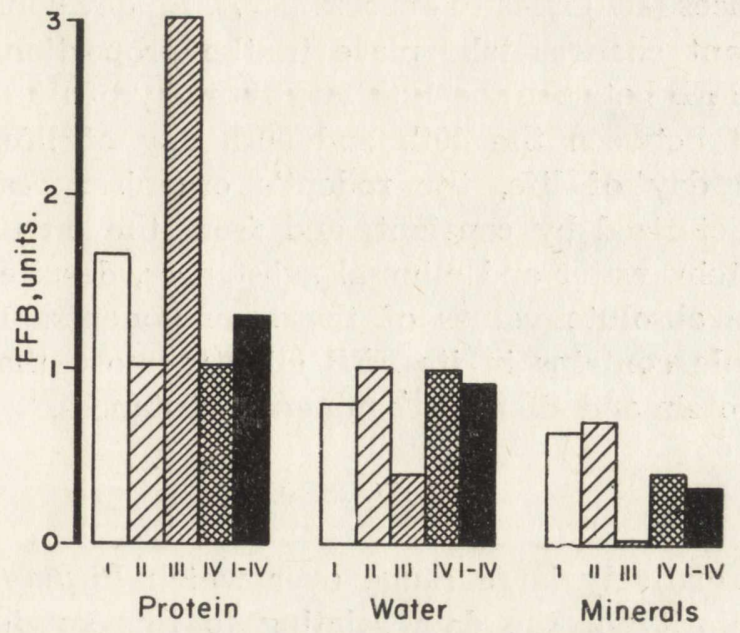

Fig. 3. Gross composition for fat-free body - rate of increase in FFB depending on individual increase of different components in successive age groups, and average for the whole study period (I-IV).

The percentage of water, protein and mineral substances in FFB varies in a way characteristic of all the mammals examined (Fig. 4). Day-old pine voles have a little more than $85 \%$ water in their $F F B$, almost $12 \%$ protein and slightly less than $2 \%$ mineral substances, whereas by the 10th day of life the amount of water drops to approx. $80 \%$, amount of protein rises to about $17 \%$, while the amount of

Table 2

Growth rate of fat-free body of Pitymus subterraneus $\left(X_{1}\right)$ depending on simultaneous influence of water $\left(X_{2}\right)$, mineral substances $\left(X_{3}\right)$ and protein $\left(X_{4}\right)$. In cases in which the multiple regression equation describing this relation did not differ significantly for the different age groups a common equation was used.

$s$ - standard error of estimate: $s_{B_{2}}, s_{B_{3}}, s_{B_{4}}-$ standard errors of regresision coefficients, $r$-coefficient of multiple correlation.

\begin{tabular}{rrcccccc}
\hline $\begin{array}{c}\text { Age } \\
\text { groups }\end{array}$ & $\mathrm{N}$ & $X_{1}=A+B_{1} X_{1}+B_{2} X_{2}+B_{3} X_{3}+B_{4} X_{4}$ & $S$ & $s_{B_{2}}$ & $s_{B_{3}}$ & $s_{B_{4}}$ & $r_{1.234}$ \\
\hline I & 53 & $X_{1}=+.012+.811 X_{2}+.643 X_{3}+1.756 X_{4}$ & .075 & .091 & .837 & .380 & .998 \\
II & 33 & $X_{1}=-.040+1.003 X_{2}+.693 X_{3}+1.080 X_{4}$ & .024 & .019 & .168 & .057 & .999 \\
III & 24 & $X_{1}=-.060+.403 X_{2}+.095 X_{3}+3.170 X_{4}$ & .081 & .180 & .544 & .507 & .997 \\
IV & 49 & $X_{1}=-0.32+1.026 X_{2}+.399 X_{3}+1.074 X_{4}$ & .110 & .067 & .307 & .198 & .997 \\
I-IV & 159 & $X_{1}=+.012+.957 X_{2}+.362 X_{3}+1.284 X_{4}$ & .088 & .028 & .179 & .090 & .999 \\
\hline
\end{tabular}

Connected groups

\begin{tabular}{lc}
\hline I-II & $X_{1}=+.007+.975 X_{2}+.669 X_{3}+1.156 X_{4}$ \\
I-IV & $X_{1}=-.021+.990 X_{2}+.464 X_{3}+1.170 X_{4}$ \\
II-IV & $X_{1}=-.056+.996 X_{2}+538 X_{3}+1.150 X_{4}$ \\
\hline
\end{tabular}


mineral substances (ash) rises to approx. 2.5\%. As development continues further important changes take place in the proportions of the basic components of FFB between the 10th and 40th day of life. These changes are less abrupt between the 40th and 50th day of life. Between the 50 th and 60th day of life, the rodent's organism reaches chemical maturity, characterized by constant, and from the on unvarying, proportions of protein, water and mineral substances, despite the continued increase in the absolute values of these components. The chemically mature pine vole contains in its $F F B$ slightly more than $72 \%$ water, about $22.5 \%$ protein and almost $5 \%$ mineral substances.

\section{DISCUSSION}

Despite the relatively large range over which Pitymys subterraneus occurs, the majority of the data relating to this species refer to its biology and ecology and reproduction in captivity. There are, however, no data on its postnatal development.

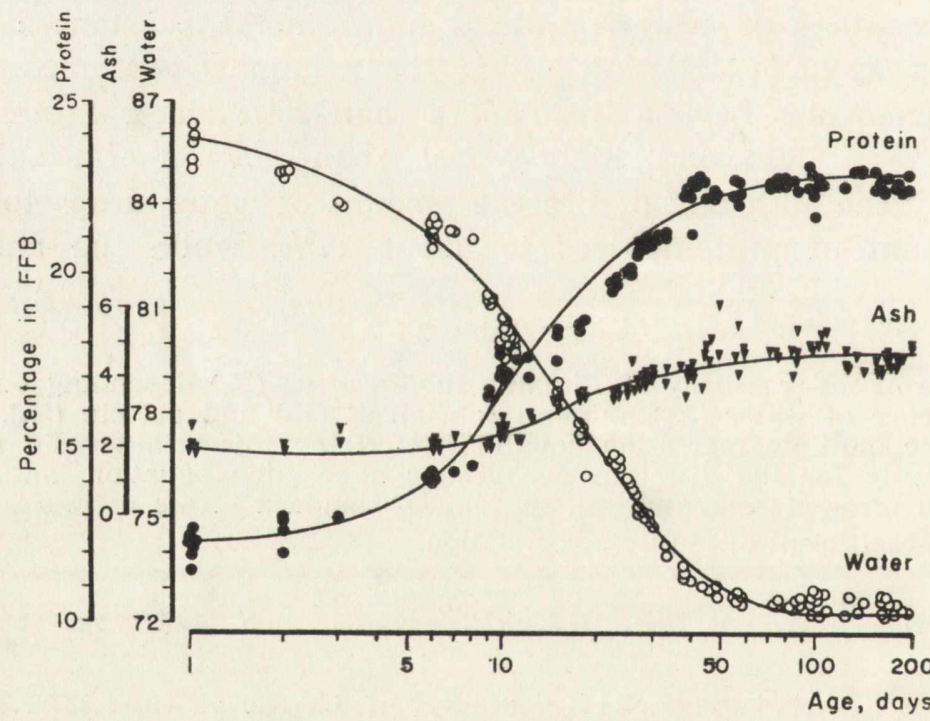

Fig. 4. Sequence of changes in proportions of protein, water and mineral substances in $F F B$ which accompany postnatal development of $P$. subterraneus. Semi-logarithmic scale.

The results of the present study showed that during postnatal development the participation of the different components in increase in body mass is not uniform. There are also variations in the participation 
of each of the components at different stages of development. In view of the similar methods used for elaborating material, the characteristics of $G B C$ development in Pitymys subterraneus may be compared with the corresponding data for the bank vole, Clethrionomys glareolus, bred in laboratories (cf. Fedyk, 1974a). Both species, despite considerable differences in their biology, have many similar features characteristic of their $G B C$ development: (1) Similar body weight on day of birth and similar GBC contents in it; (2) Quickest increase in body mass between the 10th and 20th day of life; (3) High degree of correlation between the amount of fat and body weight; (4) Very high rate of fat deposit during the suckling period in comparison with later stages of development; (5) Identical age at which chemical maturity is reached, and consequently similar sequence of changes in the percentage composition of FFB during the first two months of life.

In both species the water level in the organisms of mature individuals is chemically identical, but in $P$. subterraneus the protein level is slightly lower and level of mineral substances higher than in C. glareolus (protein $22.5 \%$ and $23.2 \%$, mineral substances almost $5 \%$ and slightly over $4 \%$ ).

There are distinct differences in the rate of increase of different FFB components at different stages of development of the species compared, particularly of increase in protein. In the pine vole protein is most rapidly deposited during the period from the 40th and 60th day of life, while in the bank vole the effect of protein on increase in FFB is minimal during this period. The effect of amount of mineral substances on increase in $F F B$ is also uneven, and in $P$. subterraneus is minimal between the 40 th and 60 th day of life, whereas in C. glareolus it is greatest between the 20th and 40th day of life, but almost uniform in other periods of development. The rate of water deposit is more varied in different periods of development in $P$. subterraneus than in the bank vole.

The comparison made justifies the conclusion that increase in gross body composition, despite similarity in general trends, is specific to each of these species.

In the light of data from literature on the time, or properly speaking, age at which pine voles enter upon reproduction (B uchalczyk, 1961; Niethammer, 1972) it would seem that chemical maturity is not closely correlated with sexual maturity, but greatly precedes it. This does not apply to $C$. glareolus, in which the age at which the animal attains chemical maturity coincides with the age of attaining. sexual maturity. 


\section{REFERENCES}

1. Bailey C. B., Kitts W. D. \& Wood A. J., 1960: Changes in the gross body composition of the mouse during growth in relation to the assessement of physiological age. Canad. J. Anim. Sci., 40: 143-155.

2. Buchalczyk A., 1961: Pitymys subterraneus (de Sélys-Long champs, 1835) under laboratory conditions. Acta theriol., 4: 282-284.

3. Drożd ż A., Górecki A. \& S a wi cka-Kapusta K., 1972: Bioenergetics of growth in common voles. Acta theriol., 17: 245-257.

4. Evans D. M., 1973: Seasonal variations in the body composition and nutrition of the vole Microtus agrestis. J. Animal Ecol., 42: 1-18.

5. Fedyk A., $1974 \mathrm{a}$ : Gross body composition in postnatal development of the bank vole. I. Growth under laboratory conditions. Acta theriol., 19: 381-401.

6. Fedyk A., $1974 \mathrm{~b}$ : Gross body composition in postnatal development of the bank vole. I. Differentiation of seasonal generations. Acta theriol., 19: 403-427

7. Fleharty E. D., Krause M. E. \& Stinnet D. P., 1973: Body composition, energy content and lipid cycles of four species of rodent. J. Mammal., 54: $426-438$.

8. Górecki A., 1965: Energy values of the small mammals. Acta theriol., 10: $333-352$.

9. H a y ward J. S., 1965: The gross body composition of six geographic races of Peromyscus. Canad. J. Zool., 43: 297-308.

10. J a mes on E. W., Jr \& M e a d R. A., 1964: Seasonal changes in body fat, water and basic weight in Citellus lateralis, Eutamias speciosus and E. amoenus. J. Mammal., 45: 359-365.

11. Niethammer J., 1972: Zur Taxonomie und Biologie der Kurzohrmaus. Bonn. zool. Beitr., 23: 290-309.

12. Sawicka-Kapusita K., 1970: Changes in the gross body composition and caloric value of the common voles during their postnatal development. Acta theriol., 15: 67-79.

13. Sawicka-Kapusta K., 1974: Changes in the gross body composition and caloric value of the bank voles during their postnatal development. Acta theriol., 19: $27-54$.

14. Schreiber R. K. \& Johnson D. R., 1975: Seasonal changes in body composition and caloric content of Great Basin rodents. Acta theriol., 20: $343-364$.

15. Sobel H., Hrubant H. E. \& Hewlett M. J., 1968: Changes in the body composition of C57 BL/6-aa mice with age. J. Gerontol., 23: 387-389.

Accepted, October 1, 1977.

Anna FEDYK, Denise FARIN i Elżbieta MALZAHN

PODSTAWOWE SKEADNIKI CIAEA PITYMYS SUBTERRANEUS Z HODOWLI LABORATORYJNEJ

\section{Streszczenie}

Zbadano podstawowe składniki ciała: tłuszcz, białko, wodę i substancje mineralne w ciągu 400 dni życia darniówek, Pitymys subterraneus, ulaboratoryjnianych w ciągu $9-11$ pokoleń. 
Uzyskane wyniki opracowano statystycznie, opisując relacje między ilością tłuszczu a ciężarem ciała równaniami regresjii prostej; tempo przyrostu beztłuszczowej masy ciała $(F F B)$ w zależności od przyrostu jej składnikóy — równaniami regresji wielokrotnej. Dla wykazania zróżnicowań w tempie przyrostu podstawowych składników ciała $(G B C)$ w trakcie rozwoju postnatalnego powyższymi równaniami opisano tendencje przyrostu w czterech etapach rozwoju.

W badanym okresie rozwoju 8-krotnie zwiększa się ciężar ciała darniówek. $\mathrm{Na}$ ten przyrost składa się, w stosunku do 1-go dnia życia, przyrost substancji mineralnych o ponad $1200 \%$, białka o $870 \%$ a wody o $400 \%$ (Fig. 1). Tłuszcz charakteryzuje największy spośród badanych składników zakres zmienności w zależności od wieku (Fig. 1), pomimo to zależność między ciężarem ciała a ilością zawartego w nim tłuszczu jest istotna w każdym okresie rozwoju (Tabela 1). Najszybszy przyrost tłuszczu ma miejsce w okresie oseskowym (Fig. 2).

Szybbkość odkładnia pozostałych składników ciała, stanowiących jej beztłuszczową masę jest różna w różnych okresach rozwoju (Tabela 2). Największe różnice w udziale składników $F F B$, w porównaniu $z$ innymi okresami rozwoju zanotowano w okresie od 41 do 60 dnia życia. Procentowy udział wody, białka i substancji mineralnych w FFB zmienia się w sposób charakterystyczny dla ssaków (Fig. 4). Dojrzałość chemiczną osiągają darniówki między 50 a 60-tym dniem życia. 